University of Nebraska - Lincoln

DigitalCommons@University of Nebraska - Lincoln

Interbasin flow in the Great Basin with special reference to the southern Funeral Mountains and the source of Furnace Creek springs, Death Valley, California, U.S.

\author{
Wayne R. Belcher \\ M. S. Bedinger \\ Jennifer T. Back \\ National Park Service \\ Donald S. Sweetkind \\ U.S. Geological Survey
}

U.S. Department of Energy, wayne_belcher@ymp.gov

Follow this and additional works at: https://digitalcommons.unl.edu/usgsstaffpub

Part of the Earth Sciences Commons

Belcher, Wayne R.; Bedinger, M. S.; Back, Jennifer T.; and Sweetkind, Donald S., "Interbasin flow in the Great Basin with special reference to the southern Funeral Mountains and the source of Furnace Creek springs, Death Valley, California, U.S." (2009). USGS Staff -- Published Research. 444.

https://digitalcommons.unl.edu/usgsstaffpub/444

This Article is brought to you for free and open access by the US Geological Survey at DigitalCommons@University of Nebraska - Lincoln. It has been accepted for inclusion in USGS Staff -- Published Research by an authorized administrator of DigitalCommons@University of Nebraska - Lincoln. 


\title{
Interbasin flow in the Great Basin with special reference to the southern Funeral Mountains and the source of Furnace Creek springs, Death Valley, California, U.S.
}

\author{
Wayne R. Belcher ${ }^{\mathrm{a}, *}$, M.S. Bedinger ${ }^{\mathrm{b}}$, Jennifer T. Back ${ }^{\mathrm{c}}$, Donald S. Sweetkind ${ }^{\mathrm{d}}$ \\ ${ }^{a}$ US Department of Energy, Office of Civilian Radioactive Waste Management, 1551 Hillshire Drive, Las Vegas, NV 89134, United States \\ ${ }^{\mathrm{b}}$ P.O. Box 790, Carlsborg, WA 98324, United States \\ ${ }^{\mathrm{c}}$ National Park Service, Water Rights Branch, 1201 Oak Ridge Dr., Suite 250, Fort Collins, CO 80525, United States \\ ${ }^{\mathrm{d}}$ US Geological Survey, P.O. Box 25046, MS 973, Denver Federal Center, Denver, CO 80225, United States
}

\section{A R T I C L E I N F O}

\section{Article history:}

Received 1 May 2008

Received in revised form 5 February 2009

Accepted 5 February 2009

This manuscript was handled by P. Baveye, Editor-in-Chief, with the assistance of Susan S. Hubbard, Associate Editor

\section{Keywords:}

Death Valley

Hydrochemistry

Springs

Ground-water flow

Ground-water recharge

\begin{abstract}
S U M M A R Y
Interbasin flow in the Great Basin has been established by scientific studies during the past century. While not occurring uniformly between all basins, its occurrence is common and is a function of the hydraulic gradient between basins and hydraulic conductivity of the intervening rocks. The Furnace Creek springs in Death Valley, California are an example of large volume springs that are widely accepted as being the discharge points of regional interbasin flow. The flow path has been interpreted historically to be through consolidated Paleozoic carbonate rocks in the southern Funeral Mountains.

This work reviews the preponderance of evidence supporting the concept of interbasin flow in the Death Valley region and the Great Basin and addresses the conceptual model of pluvial and recent recharge [Nelson, S.T., Anderson, K., Mayo, A.L., 2004. Testing the interbasin flow hypothesis at Death Valley, California. EOS 85, 349; Anderson, K., Nelson, S., Mayo, A., Tingey, D., 2006. Interbasin flow revisited: the contribution of local recharge to high-discharge springs, Death Valley, California. Journal of Hydrology 323, 276-302] as the source of the Furnace Creek springs. We find that there is insufficient modern recharge and insufficient storage potential and permeability within the basin-fill units in the Furnace Creek basin for these to serve as a local aquifer. Further, the lack of high sulfate content in the spring waters argues against significant flow through basin-fill sediments and instead suggests flow through underlying consolidated carbonate rocks. The maximum temperature of the spring discharge appears to require deep circulation through consolidated rocks; the Tertiary basin fill is of insufficient thickness to generate such temperatures as a result of local fluid circulation. Finally, the stable isotope data and chemical mass balance modeling actually support the interbasin flow conceptual model rather than the alternative presented in Nelson et al. [Nelson, S.T., Anderson, K., Mayo, A.L., 2004. Testing the interbasin flow hypothesis at Death Valley, California. EOS 85, 349] and Anderson et al. [Anderson, K., Nelson, S., Mayo, A., Tingey, D., 2006. Interbasin flow revisited: the contribution of local recharge to high-discharge springs, Death Valley, California. Journal of Hydrology 323, 276-302]. In light of these inconsistencies, interbasin flow is the only readily apparent explanation for the large spring discharges at Furnace Creek and, in our view, is the likely explanation for most large volume, low elevation springs in the Great Basin. An understanding of hydrogeologic processes that control the rate and direction of ground-water flow in eastern and central Nevada is necessary component of regional water-resource planning and management of alluvial and bedrock aquifers.
\end{abstract}

Published by Elsevier B.V.

\section{Introduction}

Interbasin flow (ground-water flow between ground-water basins through bedrock mountain ranges) in the Great Basin has been established by scientific studies during the past century (Eakin, 1966; Winograd and Thordarson, 1975; Harrill et al., 1988). Interbasin flow, though it does not occur uniformly between all basins, occurs commonly and is a function of the hydraulic gradient between basins and hydraulic conductivity of the intervening rocks. The Furnace Creek springs (Texas, Travertine, and Nevares Springs) in Death Valley, California are examples of large volume springs (flow rates greater than $1000 \mathrm{~m}^{3} /$ day [700 L/min]) in the Great Basin which have been widely accepted as being the discharge points of regional interbasin flow. Early investigators (Hunt and Robinson,

\footnotetext{
* Corresponding author. Tel.: +1 702794 5498; fax: +1 7027941350 .

E-mail address: wayne_belcher@ymp.gov (W.R. Belcher).
} 
1960; Miller, 1977) concluded the spring flow was derived from interbasin flow because of insufficient local recharge to support the flow of the springs. The path of waters that ultimately discharge at the Furnace Creek springs has been interpreted to be through consolidated Paleozoic carbonate rocks in the southern Funeral Mountains, based on similar chemical and isotopic characteristics of the ground-water in carbonate rocks at Ash Meadows, Nevada, about $50 \mathrm{~km}$ to the east (Fig. 1) (Hunt and Robinson, 1960; Winograd and Thordarson, 1975; Steinkampf and Werrell, 2001). Recent papers by Nelson et al. (2004) and Anderson et al. (2006), although not denying the existence of interbasin flow, vigorously challenge it as widely occurring phenomena; these authors suggest that the large volume springs that issue near the mouth of Furnace Creek in Death Valley (Fig. 1) derive their source largely from recharge that occurred during the Pleistocene with a small percentage of modern recharge.

Knowledge of basin water balances and the magnitude of interbasin ground-water flow is the basis for regional groundwater management and water-resource planning in the Great Basin of Nevada (Scott et al., 1971). Rapid population growth, arid conditions, and high water use have caused extensive development of available water resources. Ground-water use in some alluvial-fill basins has resulted in ground-water mining and subsidence; adjacent bedrock aquifers are increasingly being targeted for large-scale development. Such development may potentially impact local and regional water quantity and quality, existing water rights, and sensitive wildlife habitats. An understanding of hydrogeologic processes that control the rate and direction of ground-water flow in eastern and central Nevada is necessary in assessing the potential impacts of any proposed large-scale ground-water development. On a more local scale, an understanding of the magnitude of interbasin flow in southern Nevada is a critical part of defining ground-water flow paths and travel times associated with potential movement of radioactive material from the Nevada Test Site and to the characterization of the ground-water system in the vicinity of the proposed high-level radioactive waste repository at Yucca Mountain, Nevada (Hanks et al., 1999).

In this article the concept of interbasin flow in the Great Basin is revisited, using the large volume springs at Death Valley, California, as a particularly relevant example. The conceptual model of the source of Furnace Creek springs is reviewed by examining the geology and structure of the Funeral Mountains, the hydrology and geology of the basin-fill deposits of the Furnace Creek basin, and the isotope and solute geochemistry of the spring discharge and potential sources. This article also assesses the validity of recent work (Nelson et al., 2004; Anderson et al., 2006) postulating that the spring flows are the result of locally-derived and Pleistocene recharge, rather than interbasin flow.

\section{Geologic setting of the Furnace Creek springs and surrounding region}

The Furnace Creek springs and surrounding areas are located at the southern end of the Great Basin carbonate-rock province. The thickness of Paleozoic carbonate rocks in the province is as much as $8 \mathrm{~km}$ and form the major regional consolidated-rock aquifer in the eastern two-thirds of the Great Basin (Winograd and Thordarson, 1975; Bedinger et al., 1989a; Dettinger et al., 1995; Dettinger and Schaefer, 1996; D'Agnese et al., 1997; Harrill and Prudic, 1998). Large hydraulic conductivities are reported for carbonate rocks of this aquifer and result from a combination of fractures, faults, and solution channels (Winograd and Thordarson, 1975; Bedinger et al., 1989b; Belcher et al., 2001). Hydraulic tests of carbonate-rock aquifers throughout eastern and southern Nevada indicate that faults can increase the carbonate-rock transmissivity by a factor of 25 or more (Dettinger et al., 1995). Most of the large volume springs in the province are associated with the carbonate rocks, in some cases issuing directly from the carbonate rocks, such as Nevares Spring in the Furnace Creek area and Point of Rocks Spring in the Ash Meadows area (Winograd and Thordarson, 1975; Steinkampf and Werrell, 2001) (Figs. 1 and 2).

The southern Funeral Mountains are an uplifted block of Cambrian through Mississippian predominantly carbonate rocks up to 4-km thick overlying a similar thickness of Lower Cambrian to Late Proterozoic predominantly siliciclastic rocks (Cemen et al., 1985; McAllister, 1970; Fridrich et al., 2003a). The Furnace Creek fault zone, a major right-lateral strike-slip fault, bounds the range on the southwest and separates it from the Furnace Creek basin to the south (Fig. 2). The inactive Furnace Creek fault zone intersects the active northern Death Valley fault zone near the Furnace Creek springs in Death Valley (Workman et al., 2002). The southern Funeral Mountains block is bounded on the northeast by the Pahrump-Stewart Valley fault, another right-lateral strike-slip fault. Within the Funeral Mountains, carbonate rocks are truncated to the northwest by Late Proterozoic siliciclastic rocks carried in the upper plate of the Mesozoic Schwaub Peak thrust (Figs. 2 and 3). Farther to the northwest, Middle and Late Proterozoic metamorphic rocks are exposed (Workman et al., 2002) (Fig. 2). Paleozoic bedrock in the southern Funeral Mountains dips to the southeast and is disrupted by at least three major low-angle normal faults and a multitude of closely spaced, smaller-offset faults that strike in a wide range of directions, and that form a continuous network of secondary fractures (Fig. 3). Paleozoic carbonate rocks crop out in the southern Funeral Mountains and in the ranges bounding the east side of the Amargosa Desert (Fig. 2); their presence beneath basin-fill sediments, however, is subject to interpretation. Paleozoic carbonate rocks have been identified in borehole UE-25 p\#1 to the east of Yucca Mountain and in boreholes drilled in the northern, eastern, and western edges of the Amargosa Desert (Fig. 2); no deep boreholes penetrate into the Paleozoic rock underlying the thick Cenozoic sedimentary section in the center of the Amargosa Desert. Most workers agree that Paleozoic carbonate rocks are absent or severely attenuated south and west of the Furnace Creek fault zone (Stewart, 1983; Wright et al., 1991).

The Furnace Creek basin is a structural and depositional basin that is closely associated with the Furnace Creek fault zone (Wright et al., 1991, 1999) (Fig. 3). In the Furnace Creek basin, Cenozoic basin-fill rocks include older, synextensional sedimentary rocks that are folded, faulted, and intercalated with generally coeval volcanic rocks. This assemblage of older rocks is unconformably overlain by less-deformed, dominantly volcanic-free, post-tectonic alluvial sediments (Fig. 3). The basin fill consists from oldest to youngest, of the Artist Drive Formation, the Furnace Creek Formation, the Greenwater volcanics, and the Funeral Formation (Cemen et al., 1985; Greene, 1997; Wright et al., 1999) (Fig. 3). The Artist Drive and Furnace Creek Formations consist of poorly sorted fine- to coarse-grained bedded deposits, including fine-grained tuffaceous sedimentary rocks with bimodal (dacitebasalt) volcanic rocks (McAllister, 1970, 1973, 1974; Cemen et al., 1985; Wright et al., 1991; Greene, 1997). Gravelly beds are commonly in a mudstone matrix. Lacustrine mudstones and evaporites, including borates, gypsum, anhydrite and limestone occur in the Furnace Creek Formation. The Funeral Formation consists of poorly consolidated, coarse-grained alluvial material and basalt flows (Fig. 3).

The rocks of the southern Funeral Mountains and of the adjacent basins can be divided into four major hydrogeologic units, including two units in the consolidated pre-Cenozoic rocks and two units in the Cenozoic basin fill (Fig. 3). The deepest consoli- 


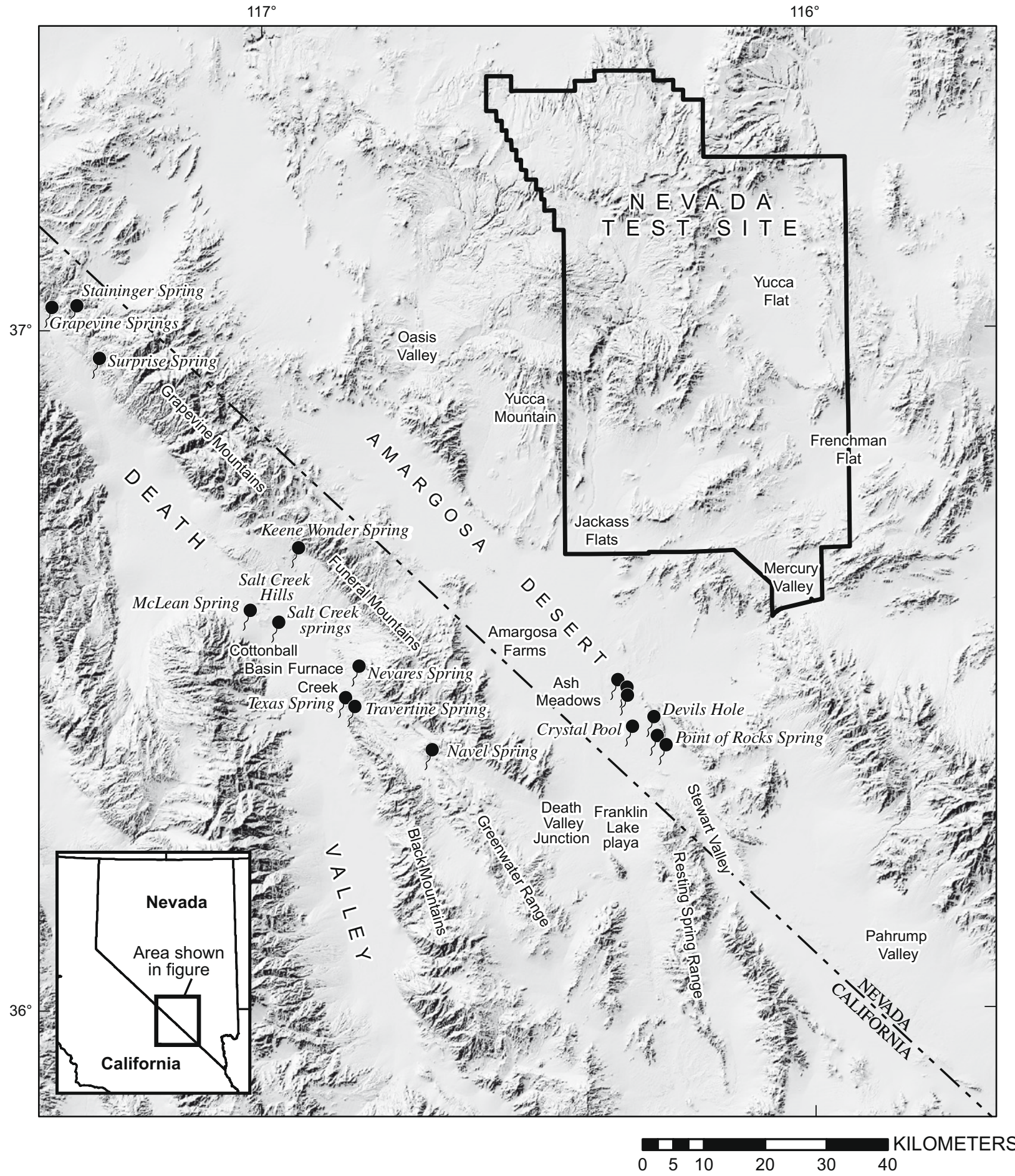

Fig. 1. Geographic and physiographic features of vicinity of Furnace Creek, Death Valley, and the southern Funeral Mountains, California.

dated-rock unit is the Late Proterozoic to Lower Cambrian, predominantly siliciclastic sedimentary rocks that are generally very low permeability except where strongly fractured (Winograd and Thordarson, 1975; Belcher et al., 2004). The approximately 4-km thick section of Lower Cambrian to Mississippian predominantly carbonate rocks, with relatively minor interbedded shale and sandstone formations, is considered to be the major consolidated-rock aquifer (Winograd and Thordarson, 1975; Belcher et al., 2004). The deeper parts of the Cenozoic basin fill, the Artist Drive and Furnace Creek Formations, are heterogeneous, but are generally of low permeability as a result of structural disruption of the few thin permeable beds and the abundance of fine-grained sedimentary rock and presence of volcanic ash (Fig. 3). The deeper Cenozoic section as a whole can therefore be generally treated as a confining unit. The poorly consolidated alluvium that forms the uppermost part of the Cenozoic section can be an excellent aquifer, both in the Furnace Creek basin where the Furnace Creek springs are seen to discharge from the Funeral Formation, and in the Amargosa Desert, where it is the major water producer in the Amargosa Farms area. 

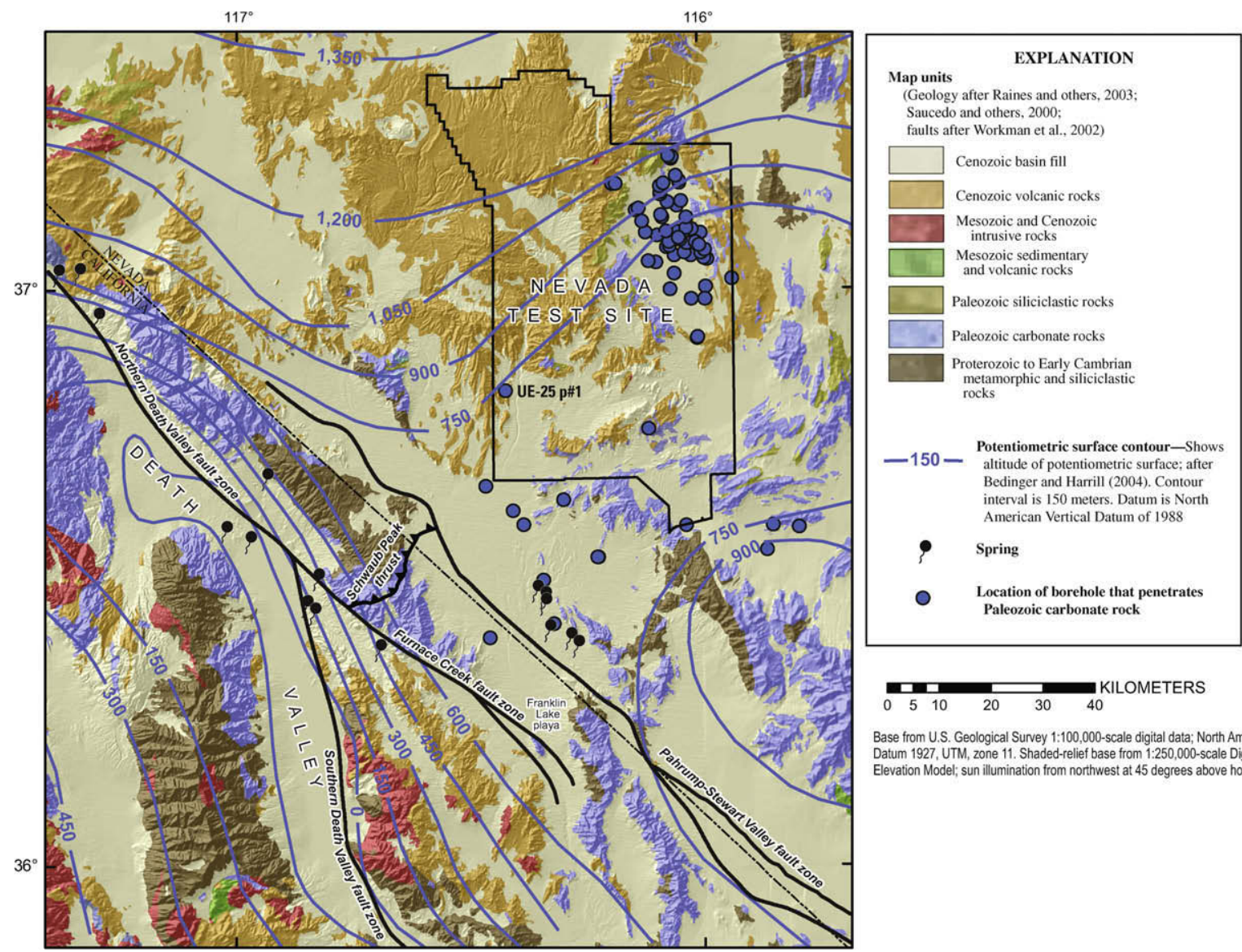

Base from U.S. Geological Survey 1:100,000-scale digital data; North American Datum 1927, UTM, zone 11. Shaded-relief base from 1:250,000-scale Digital Elevation Model; sun illumination from northwest at 45 degrees above horizon

Fig. 2. Generalized geology for the study area with regional potentiometric contours. (See above-mentioned references for further information.)

\section{Conceptual model of regional interbasin flow}

Interbasin flow in the Great Basin was suggested almost 100 years ago by Mendenhall (1909). Since then, studies of interbasin flow in the Great Basin have progressed as investigators have studied specific cases of interbasin flow based on site and regional data. Carpenter (1915) was among early investigators who thought the Paleozoic rocks enclosing the basins were impermeable, but was later convinced of interbasin flow by his study of closed basins that receive recharge in the bounding ranges but have no discharge within the basin.

Maxey and Eakin (1949) proposed an empirical method for evaluating the water budgets of closed basins. The method estimated recharge to the basin as a percentage of precipitation in altitude classes and estimated ground-water discharge as a function of phreatophytes and depth to ground-water. The Maxey-Eakin method was useful in the early delineation of regional groundwater flow, which required balancing recharge and discharge, requiring the presence of interbasin flow where the two were not equal. The method was used over the next several decades to quantify water budgets for basins in Nevada and Utah.

Regional ground-water flow systems composed of many basins were first recognized and defined in the carbonate-rock province of the Great Basin. Winograd (1963) inferred interbasin flow through the Paleozoic carbonate rocks using a potentiometric map that included the Ash Meadows area. Eakin (1966) used water budgets of several basins in southeastern Nevada to hypothesize an interbasin flow system designated as the White River system. Estimates of recharge and discharge for each basin were used to derive the amount of ground-water flow that was contributed to the down- gradient basins. The direction of the regional hydraulic gradient was recognized from the altitude of shallow water levels in adjacent basins (Eakin, 1966).

Harrill et al. (1988) used topographic and shallow water-level differences between basins to define the regional ground-water potential and direction of interbasin flow in the Great Basin. Other early studies that contributed to the understanding of interbasin ground-water flow include Eakin and Winograd (1965), Eakin and Moore (1964), Mifflin (1968), and Mifflin and Hess (1969).

Major hydrogeologic investigations were conducted at the $\mathrm{Ne}-$ vada Test Site (NTS) in Nye County, Nevada beginning in the 1960's. These studies included drilling, hydraulic testing, and hydrogeochemical and isotopic studies in conjunction with detailed geologic mapping and supporting geophysical surveys. Data from these detailed studies enabled Winograd and Thordarson (1975) to present a compelling view of interbasin flow based on continuity of the potentiometric surface from basin to basin, significant permeability and in rock sequences separating the basins, and similarity of hydrogeochemical and isotopic ground-water characteristics. Winograd and Thordarson (1975) were able to show that interbasin flow occurred through the carbonate-rock ridges that separate Yucca Flat, Frenchman Flat, Mercury Valley, and Ash Meadows in the NTS region (Fig. 1). Winograd and Thordarson (1975) were also able to identify rock sequences of low permeability and areas of restricted interbasin flow in the NTS region.

This geologic and hydrologic work in the Great Basin region over several decades led to the conclusion that ground-water flow is composed of an interconnected, complex ground-water flow system. Several ground-water flow models have been constructed by various workers using this conceptual model of interbasin flow; 


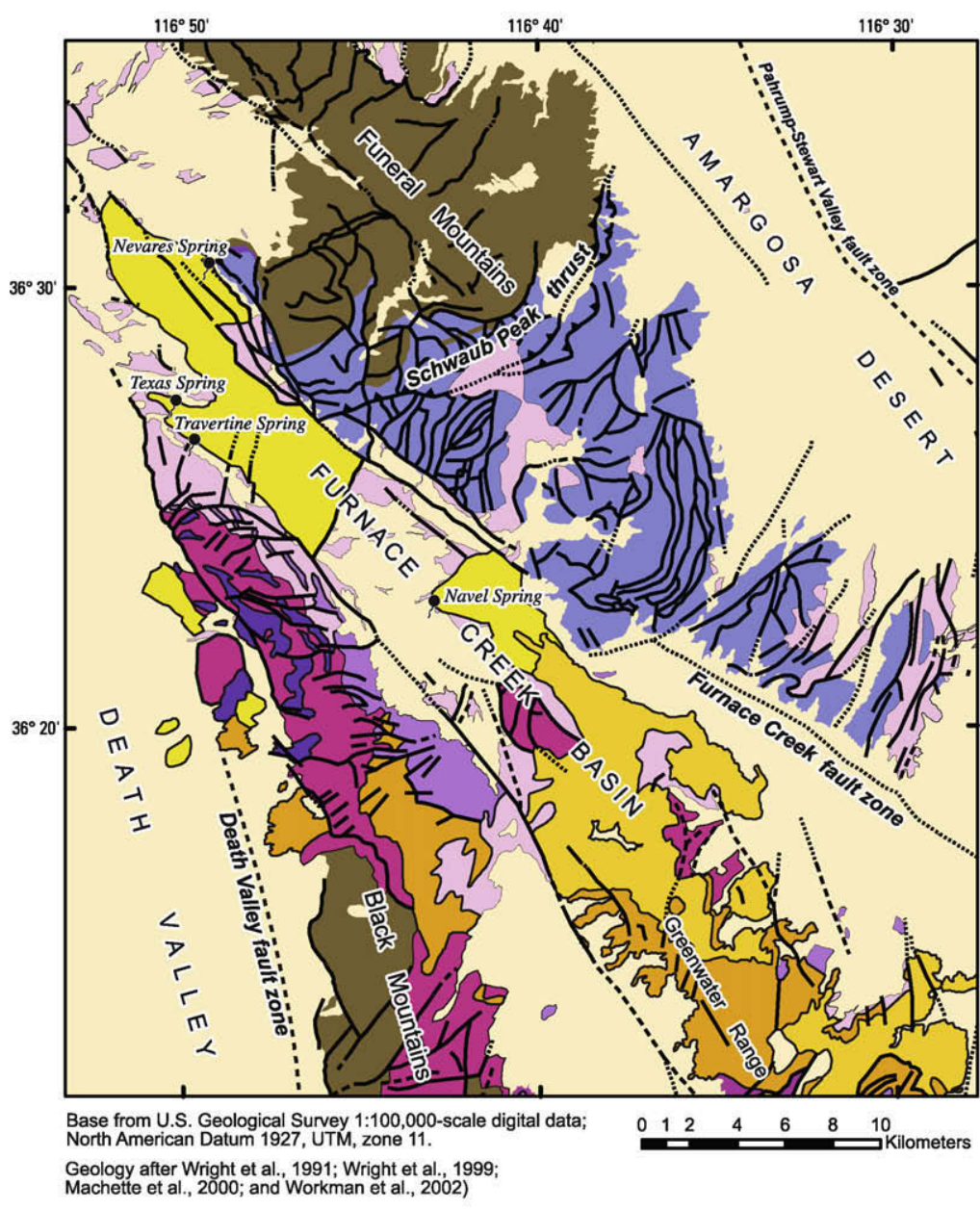

\begin{tabular}{|c|c|c|c|}
\hline FORMATION & THICKNES & LITHO & LOGY \\
\hline $\begin{array}{l}\text { Quaternary } \\
\text { alluvium }\end{array}$ & variable & & $\begin{array}{l}\text { unconsolidated } \\
\text { sand and grav }\end{array}$ \\
\hline $\begin{array}{l}\text { Funeral } \\
\text { Formation }\end{array}$ & $\begin{array}{l}100-300 \mathrm{~m} \\
400 \mathrm{~m}\end{array}$ & 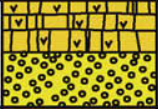 & $\begin{array}{l}\text { Basalt flows } \\
\text { Conglomerate } \\
\end{array}$ \\
\hline $\begin{array}{l}\text { Greenwater } \\
\text { volcanics }\end{array}$ & $\begin{array}{l}\text { variable, } \\
\text { up to } 400 \mathrm{~m}\end{array}$ & 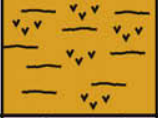 & $\begin{array}{l}\text { Dacite lava flow } \\
\text { and nonwelded }\end{array}$ \\
\hline $\begin{array}{c}\text { Furnace Creek } \\
\text { Formation }\end{array}$ & $\begin{array}{l}\text { up to } \\
1200 \mathrm{~m}\end{array}$ & 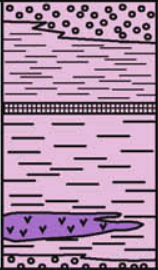 & $\begin{array}{l}\text { Conglomerate } \\
\text { Tuffaceous silts } \\
\text { and sandston } \\
\text { Gypsum, minor } \\
\text { with mudstone } \\
\text { Tuffaceous mu } \\
\text { sandstone, m } \\
\text { Basalt flows an } \\
\text { nonwelded tu } \\
\text { Conglomerate } \\
\end{array}$ \\
\hline $\begin{array}{l}\text { Artist Drive } \\
\text { Formation }\end{array}$ & $500 \mathrm{~m}$ & 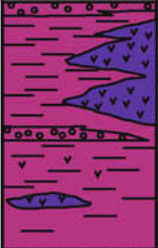 & $\begin{array}{c}\text { Tuffaceous sa } \\
\text { hyolite lava f } \\
\text { nonwelded tu } \\
\text { Conglomerate } \\
\begin{array}{c}\text { Tuffaceous silts } \\
\text { and sandston } \\
\text { basalt flows }\end{array}\end{array}$ \\
\hline $\begin{array}{l}\text { Paleozoic } \\
\text { carbonate } \\
\text { rocks, undivided }\end{array}$ & $\begin{array}{l}\text { up to } \\
4000 \mathrm{~m}\end{array}$ & $\frac{1}{11}$ & $\begin{array}{l}\text { Consolidated li } \\
\text { and dolomite }\end{array}$ \\
\hline $\begin{array}{l}\text { Paleozoic } \\
\text { and older } \\
\text { non-carbonate } \\
\text { rocks, undivided }\end{array}$ & $\begin{array}{l}\text { up to } \\
4000 \mathrm{~m}\end{array}$ & $\mid \begin{array}{ccc}1 & 1 & 1 \\
-1 & 1 \\
1 & 1 & 1\end{array}$ & $\begin{array}{l}\text { Consolidated s } \\
\text { shale, minor d } \\
\text { schist, gneiss } \\
\text { granitic rocks }\end{array}$ \\
\hline \multicolumn{4}{|c|}{$\begin{array}{l}\text { Fault - undifferentiated; long-dash where } \\
\text { concealed, short-dash where inferred } \\
\text { Thrust fault - teeth on upper plate, } \\
\text { short-dash where inferred }\end{array}$} \\
\hline
\end{tabular}

Fig. 3. Geologic map and generalized stratigraphic column of the Furnace Creek basin.

Belcher et al. (2004) present a review of ground-water modeling in the Death Valley region. Most recently, regional ground-water flow in the Death Valley regional ground-water flow system (DVRFS) has been simulated by Belcher (2004). As a part of this work, the potential on the regional ground-water flow system (Fig. 2) was mapped (Bedinger and Harrill, 2004), and used to define the boundary conditions of the DVRFS. Nelson et al. (2004, p. 349) postulate that ground-water flow models that incorporate the interbasin flow conceptual model may be incorrect or incompletely conceptualized. However, the interdisciplinary nature of these modeling activities and their successful integration of geologic, hydrologic, and geochemical data, lends credibility to the interbasin flow concept because of their explanatory power.

A number of studies have provided values for components of the ground-water mass balance of the basins in the Death Valley region and quantitatively define the interbasin flows (Belcher, 2004; Bedinger and Harrill, 2007). Pistrang and Kunkel (1964) are among the few early investigators that expressed the view that the source of the Furnace Creek springs is derived from local recharge.

\section{Interbasin flow and the Furnace Creek springs}

The Furnace Creek springs in Death Valley, California are an example of large volume springs that are widely accepted as being the discharge points of regional interbasin flow. The flow path has been interpreted historically to be through consolidated Paleozoic carbonate rocks in the southern Funeral Mountains. Such a conceptualization is supported by a variety of geologic, hydrologic, and geochemical evidence.

\section{Geologic factors affecting flow at the Funeral Mountains}

Detailed hydrogeologic mapping of the southern Funeral Mountains (Fridrich et al., 2003a,b,c) and the adjacent Furnace Creek basin (McAllister, 1971; Greene, 1997) establishes the hydrogeologic environment permissive of the ground-water flow through the Paleozoic carbonate rocks of the Funeral Mountains and northwestward movement of the ground-water along carbonate rocks in the Furnace Creek fault zone. Mapping of the southeastern Funeral Mountains by McAllister (1971) and Fridrich et al. (2003b) has shown that many major faults and much of the bedding within this range (Fig. 3) are oriented parallel to the presumed direction of ground-water flow, much as Winograd and Thordarson (1975) showed for basins in the NTS region. Brittle deformation formed a network of closely spaced secondary faults that transect bedding and strike in every direction, creating a fault-fracture mesh that is well connected (Fridrich et al., 2003a). The few siliciclastic and shale interbeds that are present within the Paleozoic carbonate rocks are cut by numerous faults with offsets that exceed the thicknesses of these interbeds. The dismemberment of these units creates insufficient continuity in the siliciclastic rocks to effectively 
block or interrupt ground-water flow through the carbonate-rock aquifer (Bredehoeft et al., 2005a, p. 6).

Carr (1988) emphasized the importance of regional tectonic extension to ground-water flow which has produced northeaststriking open faults within the Paleozoic carbonate rocks. For example, Devils Hole, a fissure with passageways up to $2 \mathrm{~m}$ wide extending to a depth of at least $130 \mathrm{~m}$ below the water table, developed entirely along a single northeast-striking fault plane, despite the fact that it cuts joints, bedding planes and older northwest-striking faults (Riggs et al., 1994). The existence of Devils Hole demonstrates that fractures and faults in this region of extension can be, and are, important conduits for ground-water rather than barriers as implied by Anderson et al. (2006).

Faunt (1997) further indicates that faulting in the Death Valley region can both enhance and restrict the movement of groundwater. By comparing the crustal stress field with fault trace orientation, potential effects on the ground-water flow were analyzed. Faunt (1997) indicates that northeast-striking faults in relative tension provided the opportunity for being conduits, while northwest-striking faults in relative compression or shear were more likely to be ground-water barriers.

The common assumption of many investigators that the siliciclastic rocks in the Death Valley region and specifically in the southern Funeral Mountains always act as confining units of very low permeability is incorrect and can be counterproductive to a complete understanding the flow system. Deep burial of the siliciclastic rocks of the Death Valley region cause them to lose most, if not all, original interstitial porosity through metamorphism. However, Bedinger and Harrill (2007) have pointed out that pervasive fracture-faulting may provide secondary permeability in these brittle rocks where not deeply buried, as in the southern Funeral Mountains. Belcher et al. (2001) report a transmissivity of the Stirling Quartzite of $300 \mathrm{~m}^{2} /$ day from a well test in the southern Funeral Mountains. This is the greatest known estimate of transmissivity for the siliciclastic rocks in the Death Valley region, but even with smaller transmissivity, significant flow would be possible through both the carbonate and the siliciclastic rocks of the southern Funeral Mountains.

\section{Hydraulic evidence of flow at the Funeral Mountains}

The Death Valley region provides an important example of the influence of consolidated-rock permeability on regional heads and flow paths (Fig. 2). Exposures of relatively low permeability Proterozoic metamorphic and siliciclastic rocks in the Funeral Mountains are associated with a steep hydraulic gradient along the east side of Death Valley (D'Agnese et al., 1997; Bedinger and Harrill, 2004). In addition to low-permeability rocks, steep gradients are produced through the carbonate rocks in the Funeral Mountains as a result of the topographic relief of Death Valley (Bredehoeft et al., 1982; Bedinger and Harrill, 2004). Large volume springs are present in Death Valley only adjacent to the northern part of the Grapevine Mountains and the southern part of the Funeral Mountains (Steinkampf and Werrell, 2001), where relatively permeable Paleozoic carbonate rocks allow ground-water flow; no large volume springs are present where the low-permeability consolidated-rock units are exposed (Fig. 2). Grapevine, Staininger and Surprise Springs appear to result from interbasin flow to Death Valley though carbonate rocks of the Grapevine Mountains (Fig. 2). The springs at both Ash Meadows and Furnace Creek are spatially located near outcrops of Paleozoic carbonate rock (Fig. 2).

Bredehoeft et al. (2005b) and Bedinger and Harrill (2006) assimilate information from historic and recent studies (including Fridrich et al., 2003a,b,c) to describe and illustrate the geologic and hydrologic conditions of spring occurrence at Furnace Creek. The route of the ground-water to the springs is through the carbonate rocks in the southeast part of the Funeral Mountains, and then conveyed in the Furnace Creek fault zone or in adjacent carbonate rocks to Nevares Spring and to permeable gravel in the upper part of the Funeral Formation. The upper gravels are underlain by fine-grained playa deposits revealed by geophysical surveys and test holes (Machette et al., 2000; Bredehoeft et al., 2005a). Flow to Travertine and Texas Springs (Fig. 2) is ultimately through the upper gravel beds of the Funeral Formation, discharging where the formation is terminated by erosion. Flow to Nevares Spring is in the Bonanza King Formation (part of the regional carbonate aquifer), flowing northeast parallel to the strike of the Furnace Creek fault zone to the spring outlet where the formation is terminated by faulting.

\section{Geochemical controls on ground-water flow to Furnace Creek springs}

Water discharging at Furnace Creek springs chemically and isotopically resembles water discharging from springs at Ash Meadows (Steinkampf and Werrell, 2001). Anderson et al. (2006) attempt to refute this by stating (p. 283) that “... solute analyses and chemical modeling for waters from the basin-fill aquifers in the Amargosa Desert indicate flow toward Franklin Lake playa, not west toward Furnace Creek". Their argument does not address the concept of flow of ground-water from Ash Meadows through the carbonate-rock aquifer beneath the basin-fill deposits of the Amargosa Desert. Franklin Lake Playa (Figs. 1 and 2) is an intermediate area of discharge in the southern Amargosa Desert and flow toward Franklin Lake Playa does not preclude other flow paths to Furnace Creek springs. Additionally, they do not identify the waters used to represent the basin-fill deposits in the Amargosa Desert for solute analysis and chemical modeling, despite pronounced spatial differences in water chemistry throughout the basin.

Winograd and Thordarson (1975) suggested that the source of water discharging from springs in the Furnace Creek area may be a mixture of water from Oasis Valley and Ash Meadows. They noted that the chemical quality of water in the basin-fill deposits varied greatly from place to place within the central Amargosa Desert. Water in the area west of the Ash Meadows spring line (Fig. 1) was of a calcium magnesium, sodium bicarbonate facies. Water from the west-central and northwestern parts of the Amargosa Desert resembled the sodium sulfate bicarbonate water discharging at the Furnace Creek springs. Water of mixed character from shallow wells in the Death Valley Junction area was described as a playa facies, which was limited to wet playas and shallow wells in areas of ground-water discharge. Winograd and Thordarson (1975) conclude that water enters the Amargosa Desert from the east across the spring line in Ash Meadows, from the north in the Jackass Flats area, and from the northwest in the Oasis Valley area. As a result, ground-water in the central Amargosa Desert is probably derived from at least three different sources and exhibits different chemical qualities dependent on location in the basin.

The unique behavior of the rare earth elements (REE) makes them suitable as tracers of geochemical processes. Studies have shown that ground-water and some surface waters can inherit their REE signatures from the rock through which the water has flowed (Smedley, 1991; Fee et al., 1992). Johannesson et al. (1997) used REE signatures to evaluate ground-water flow-paths and mixing in the carbonate aquifer of southern Nevada. Johannesson et al. (1997) point out that the water discharging at Furnace Creek and Ash Meadows springs have similar REE signatures, whereas water from wells in the Amargosa Desert basin-fill aquifer is quite different. Johannesson et al. (1997) conclude that, based on REE data, the primary component of water discharging at Furnace Creek springs appears to be through-flow Ash Meadows groundwater, which may or may not contain a smaller component of shallow basin-fill ground-water from the Amargosa Desert. This work supports the theory of ground-water flow through the frac- 
tured carbonate rocks beneath Ash Meadows and the southern Funeral Mountains.

\section{Evaluating the source of waters for the Furnace Creek Springs}

In contrast to the generally accepted interbasin hydrologic regimen, Nelson et al. (2004) and Anderson et al. (2006, pp. 285, 286 and their Figs. 5-7) propose that the source of the springs is derived from an aquifer in the Furnace Creek drainage basin. They suggest that the current discharge is from ground-water recharged during the recent pluvial (13,000 years b.p.) augmented by a small, but unspecified, percentage of modern recharge. They propose that ground-water is transmitted to the Furnace Creek springs in sand and gravel units of the Furnace Creek and Funeral Formations. The sand and gravel beds are interbedded with beds of fine-grained sediments, evaporite beds and volcanic deposits that would act as “...confining units..." and "...probably restrict upward leakage from depth, thereby limiting the rate at which the system drains via spring discharge" (Anderson et al., 2006, p. 185). They further suggest that the sodium bicarbonate dominance of the Furnace Creek waters indicate a local water source from basin-fill deposits. The great thickness of the basin-fill deposits is also postulated to be sufficient to explain the temperatures of the discharge waters, allowing for deep flow of locally recharged waters. Spring hydrographs, according to Anderson et al. (2006) indicates fluctuations corresponding to modern climate states. They further assert that the catchment basin of the Furnace Creek springs could support these large-flow springs. Both articles also state that the hydrogeology of the southern Funeral Mountains and the Amargosa Desert do not support interbasin flow through a fractured carbonate rock system. Anderson et al. (2006) suggest that, while the potential measurements and chemical mass balance models can support an interbasin flow interpretation, other geochemical indicators do not. According to Anderson et al. (2006) carbon isotope data preclude flow paths from Ash Meadows to Furnace Creek, as do strontium and uranium isotopes.

In evaluating the relative contributions of interbasin flow and local recharge to the Furnace Creek springs, we separate our discussion below into hydrologic and geochemical arguments. Hydrologic considerations include the hydraulics, permeability, and storage of aquifers within the Furnace Creek basin, the temperature of the Furnace Creek springs and resulting requirements for depth of circulation, the implications of constancy of spring discharge, and the quantity of modern recharge available in this extremely arid watershed to provide springs with a local source of water. Geochemical arguments include the implications of the low sulfate content of the spring waters, interpretation of stable isotope data relative to modern recharge, and evaluation of mass balance modeling studies to evaluate flow paths.

\section{Hydrologic considerations}

\section{Aquifer permeability and depth of circulation}

Geologic information indicates the absence of water-bearing strata in the Furnace Creek Formation of sufficient permeability and continuity to provide the flow to the Furnace Creek springs. Geophysical and geologic information provide no indication of a continuous or interconnected system of permeable beds in the Furnace Creek basin that would convey significant quantities of ground-water. Fridrich et al. (2003a) describe the basin-fill deposits of the Furnace Creek basin as generally of low permeability, but locally with some thin, highly permeable beds that can only be traced over short distances. They conclude that the permeable beds probably lack sufficient continuity to have a significant impact on regional ground-water flow (Fridrich et al., 2003a; Bredehoeft et al., 2005a). Hunt et al. (1966) describe the Furnace Creek Formation as containing playa deposits and indicate that the low-permeability beds of the Furnace Creek Formation are uplifted in the floor of Death Valley north of Cottonball Basin, resulting in emergence of springs up gradient of these basin-fill deposits, implying generally low permeability in these rocks. On the basis of single-well aquifer tests, the hydraulic conductivity of the basin-fill deposits of the Furnace Creek basin range from 0.01 to $0.4 \mathrm{~m}$ /day, roughly an order of magnitude less than that of unconsolidated alluvial aquifers or fractured carbonate-rock aquifers (Belcher et al., 2001).

The maximum temperature of ground-water in transit to the Furnace Creek springs requires circulation to a depth of about $1300 \mathrm{~m}$ beneath and near the mouth of Furnace Creek, based on silica geothermometer calculations. According to Hunt et al. (1966, p. B45), the temperature of the spring discharge in the Furnace Creek area is approximately $35^{\circ} \mathrm{C}$. The maximum temperature of the ground-water in transit to the spring outlets is $58^{\circ} \mathrm{C}$, calculated on the basis of silica geothermometers by Anderson (2002, their Table 7, mean of six calculations). Pluvial recharge occurred in the higher parts of the basin, as does modern recharge. Inferring from the modern relation of altitude to recharge and assuming the average altitude of recharge to be $1220 \mathrm{~m}$ in the Furnace Creek basin, the average temperature of the recharge water should be $14.6{ }^{\circ} \mathrm{C}$ (Rowlands, 1993). Disregarding that the temperature of the water recharged during the pluvial was probably less than present, the water recharging Anderson et al.'s (2006) conceptual aquifer would need to undergo an increase in temperature of about $43{ }^{\circ} \mathrm{C}$. Geothermal gradients in the Death Valley region of about $33^{\circ} \mathrm{C} / \mathrm{km}$ are reported by Mase et al. (1979) and Steinkampf and Werrell (2001). This geothermal gradient would require the ground-water to circulate to an average depth of $1300 \mathrm{~m}$. Geophysical studies of Blakely and Ponce (2001) and Bredehoeft et al. (2005a) indicate that this depth is known to be present in a limited area of the Cenozoic deposits near the mouth of the Furnace Creek drainage. Given the geophysical estimate of maximum depth of Cenozoic deposits and the calculated maximum temperature of the ground-water supplying the springs, it is questionable that the Cenozoic deposits could yield the spring flow with the observed geothermal characteristics. Another implication of the depth of ground-water circulation is the requirement for a mechanism to bring the ground-water to the surface from this great depth.

\section{Spring conduits and head necessary to support spring flows}

Based on the geology of the Furnace Creek basin, there is no evidence of a natural conduit through confining beds, nor sufficient hydraulic head to bring ground-water from a depth of $1300 \mathrm{~m}$ to the Furnace Creek springs. The configuration of the Furnace Creek flow system as proposed by Nelson et al. (2004) and Anderson et al. (2006) does not explain why the Furnace Creek springs occur in their topographic and geologic location. The confining units in the section would not simply "restrict upward leakage" (Anderson et al. 2006, p. 285), but would effectively prevent spring discharge because of their extremely low hydraulic conductivities and low hydraulic gradient from depth in the aquifer to above the spring outlets. In addition, such a discharge mechanism, were it to occur, would require a barrier or termination of the basin-fill aquifer to prevent the ground-water from discharging farther down valley on the floor of Death Valley at lower elevation that the spring outlets and along paths of less resistance to flow. Also, if the groundwater emerged by upward cross bed leakage, the discharge would occur at the lowest surface elevation, which would be along the channel of Furnace Creek at lower elevation than the springs. The emergence of the springs from their proposed basin-fill aquifer would require a permeable conduit through the confining units to bring ground-water from a depth of approximately $1300 \mathrm{~m}$, 
based on the temperature of the emerging waters. Neither detailed geologic mapping nor geophysical studies in the Furnace Creek springs area have detected pathways in the subsurface that would convey ground-water from great depth in the Furnace Creek Formation (McAllister, 1970; Blakely and Ponce, 2001; Bredehoeft et al., 2005a).

\section{Aquifer hydraulics and storage considerations}

The pluvial ground-water storage in the ground-water basin proposed by Anderson et al. (2006) would not sustain the present-day flow of the Furnace Creek springs. The hydraulics and storage capability of the Furnace Creek basin to provide the flow of the springs from ground-water storage derived from the recent pluvial, 13,000 years b.p. was evaluated in the context of the flow system proposed by Nelson et al. (2004) and Anderson et al. (2006). The characteristics of the Furnace Creek basin and aquifer proposed by Nelson et al. (2004) and Anderson et al. (2006) are given in Table 1. The ground-water storage in the flow system available for flow to the springs was calculated from dimensions and properties given by Anderson et al. (2006) in Table 1. Nelson et al. (2004) and Anderson et al. (2006) describe a confined aquifer, but specify a specific yield of 0.25 , a value characteristic of an unconfined aquifer. The drainable storage would be the volume of the aquifer above the spring outlets to the level of the potentiometric surface, given as $500 \mathrm{~m}$ (Table 1). We calculate a lesser volume because: (1) the Cenozoic deposits do not underlie about $40 \%$ of the Furnace Creek basin and (2) an aquifer in the Cenozoic deposits would be confined. The head in the proposed aquifer would be above the land surface near the springs and for a distance up gradient from the springs. A confined coefficient of storage would apply near the springs. Over the long term slow drainage as the potentiometric surface is lowered would contribute to the spring flow but over the long term the storage coefficient would be less than the proposed specific yield of 0.25 .

Spring discharge at the end of the pluvial, 13,000 years b.p., would initially be large and decline with time during the simulation as the storage in the system was depleted. Based on the potential range of transmissivity of the aquifer, as discussed under permeability, below, we conclude the aquifer is not permeable enough to support the present-day flow of the springs. However, assuming as proposed, that the initial spring flow were $5 \times 10^{6} \mathrm{~m}^{3} /$ year, the storage is as great as proposed, and that flow rate could be maintained, the aquifer would be completely emptied in 12,800 years.

\section{Estimating the quantity of modern recharge}

Modern recharge is not sufficient to provide the flow of the Furnace Creek springs. Anderson et al. (2006, their Table 3, p. 289) estimate the catchment basin of Furnace Creek to be approximately $513 \mathrm{~km}^{2}$. Anderson et al. (2006) believe that enough water was recharged in this relatively small catchment basin during the Pleistocene to provide the current discharge rate of $5000,000 \mathrm{~m}^{3}$ / year $(9500 \mathrm{~L} / \mathrm{min})$ to the Furnace Creek springs. By this logic, springs contained in larger catchment basins should have had even greater amounts of water recharged during the Pleistocene, resulting in greater present-day discharges. Ash Meadows is about $50 \mathrm{~km}$ east of Furnace Creek, so it should experience about the same climatic and recharge conditions through time. Springs in Ash Meadows currently discharge about 21,000,000 $\mathrm{m}^{3}$ /year (Winograd and Thordarson, 1975) and lie in a catchment basin with an area of $11,700 \mathrm{~km}^{2}$. The current discharge of Ash Meadows springs is about 4 times greater than that in Furnace Creek springs, yet it lies within a catchment basin over 20 times as large. If spring discharge at Ash Meadows, like that at the Furnace Creek springs, is mostly from local recharge, why is not greater discharge seen at the springs of Ash Meadows?

Anderson et al. (2006, p. 298) assert that the discharge rates of mountain springs can be used as surrogates of modern local recharge. By using a water balance approach, the estimate the amount of recharge that supports the mountain springs. This recharge estimate is then applied over the entire basin to indicate that the "current climate is producing at least 20\% and up to $300 \%$ of the recharge required to sustain flows at Furnace Creek" (Anderson et al., 2006, p. 298). Applying a single recharge rate for high-elevation mountain springs over the entire basin is not a valid approach and could overestimate the amount of recharge available to the Furnace Creek springs. Precipitation, the source of recharge to ground-water in the Great Basin, increases with altitude, whereas the potential evapotranspiration concomitantly decreases. This inverse relation is the basis for an empirical relation where no precipitation becomes recharge at altitudes below $1500 \mathrm{~m}$ and the potential for recharge increases rapidly at higher altitudes (Maxey and Eakin, 1949). It should be noted that the Maxey and Eakin (1949) relationship is valid only for current climatic conditions, not pluvial conditions. The total extent of area

Table 1

Hydrologic characteristics of the Furnace Creek Basin from Nelson et al. (2004), Anderson (2002), and Anderson et al. (2006).

\begin{tabular}{|c|c|c|}
\hline Characteristic & Value $^{a}$ & Comment \\
\hline Area & $513 \mathrm{~km}^{2}$ & $\begin{array}{l}\text { Area of the surface outcrop of the Cenozoic rocks composing the } \\
\text { Nelson-Anderson aquifer is less than total basin area }\end{array}$ \\
\hline Transmissivity & Not given & \\
\hline Storage coefficient & 0.25 & $\begin{array}{l}\text { The specific yield would be an unconfined aquifer, however, system } \\
\text { as described by Anderson et al. (2006) would be confined. The } \\
\text { storage coefficient for a confined aquifer system would be in the } \\
\text { order of } 0.001 \text { or less. }\end{array}$ \\
\hline Spring discharge rate & $9.5 \mathrm{~m}^{3} / \mathrm{min}$ or $5 \times 10^{6} \mathrm{~m}^{3} /$ year & \\
\hline $\begin{array}{l}\text { Average height of ground-water level } \\
\text { above spring outlets }\end{array}$ & $500 \mathrm{~m}$ & \\
\hline $\begin{array}{l}\text { Drainable volume of ground-water above } \\
\text { spring outlets }\end{array}$ & $\begin{array}{l}6.4 \times 10^{10} \mathrm{~m}^{3} \text { calculated based on basin area, specific } \\
\text { yield and height of water level above springs as } \\
\text { specified by Anderson et al. (2006) }\end{array}$ & $\begin{array}{l}\text { The storage above the spring outlets available for spring flow because } \\
\text { of the smaller area of Cenozoic deposits in the basin and the smaller } \\
\text { effective storage coefficient of the deposits }\end{array}$ \\
\hline $\begin{array}{l}\text { Average maximum temperature of } \\
\text { ground-water }\end{array}$ & $\begin{array}{l}58^{\circ} \mathrm{C} \text { from silica geothermometer data in Anderson } \\
(2002)\end{array}$ & \\
\hline $\begin{array}{l}\text { Depth of ground-water circulation in } \\
\text { route to springs }\end{array}$ & Not given & $\begin{array}{l}\text { About } 1300 \mathrm{~m} \text { required to heat ground-water to maximum } \\
\text { temperature, } 58^{\circ} \mathrm{C} \text {. }\end{array}$ \\
\hline $\begin{array}{l}\text { Path of ground-water from depth to spring } \\
\text { outlets }\end{array}$ & Vertical leakage across confining beds & $\begin{array}{l}\text { Springs would emerge from permeable pathways, see discussion in } \\
\text { text. }\end{array}$ \\
\hline
\end{tabular}

a Values are from Nelson et al. (2004), Anderson (2002) and Anderson et al. (2006). 
of Furnace Creek basin that lies above $1500 \mathrm{~m}$ and has the potential for significant recharge is about $44 \mathrm{~km}^{2}$ or less than $10 \%$ of the basin. Contrary to Anderson et al.'s (2006) interpretations of published recharge estimates, present-day recharge rates are inadequate to supply the present-day discharge of Furnace Creek springs.

\section{Relation between precipitation and spring discharge}

Monthly mean spring discharge at Travertine and Texas Springs and monthly precipitation recorded at the station in Death Valley were evaluated to identify possible correlation (Fig. 4). Precipitation data from the National Climate Data Center (NCDC, 2007) weather station located in Death Valley, California were evaluated for the period from 1990 through 2005. Mean annual precipitation for the period 1990-2005 was $6.9 \mathrm{~cm}$ per year, with great variability from year to year. The driest year during this period was 1994 , and the wettest year was 2005. Periods of two or more years of greater than average precipitation occurred in 1992-1993, 19971998, and 2003-2005. Monthly discharges from Travertine and Texas Springs exhibit no apparent trend and varied less than 10 percent of the mean between 1990 and 2006 (Fig. 4). Similar records in Pistrang and Kunkel (1964) illustrate the extended periods of relatively constant discharge from the springs at Furnace Creek. In sum, no apparent correlation was observed between monthly precipitation and spring discharge.

A sharp peak in discharge occurs at Nevares Spring on the day of the Landers earthquake in 1992, and a second sharp peak occurs on the day of the Hector Mine earthquake in 1999 (Fig. 4). Anderson et al. (2006) attribute these sharp peaks to the relatively wet period of 1992-1993 and 1998 based on the Palmer drought severity index for southern Nevada (Fig. 4). However, significantly more amounts of precipitation fell during the period 2003-2005, with a mostly negative Palmer drought severity index for the same time, yet no increase in discharge was observed (Fig. 4). Similarly, all three springs experienced an increase in discharge corresponding to the time of the earthquakes. Similar increases in water levels that correspond to the Landers and Hector Mine earthquakes are evident in wells up gradient of the Furnace Creek springs in the Amargosa Desert (Fenelon and Moreo, 2002).

An increase in post-seismic ground-water discharge through a spring may be caused by an increase in fracture conductance (Muir-Wood and King, 1993), or an increase in the subsurface fluid pressure or permeability in the formation (Rojstaczer and Wolf, 1992; Roeloffs et al., 1995). The response of a spring to an earthquake is based on aquifer properties and the physical setting of the spring. Nevares Spring, which exhibited the sharpest signals, emerges from a travertine mound about $30 \mathrm{~m}$ from an outcrop of Bonanza King Formation. Texas Spring, which exhibited the most attenuated signal, emerges from Quaternary gravels underlain at shallow depth by lacustrine deposits.

\section{Geochemical considerations}

\section{Sulfate content of Furnace Creek springs}

Ground-water in the Furnace Creek Formation typically contains significant sulfate, which would be a prominent anion in the waters of the Furnace Creek springs (Texas, Travertine, and Nevares) if the Furnace Creek Formation was their source. McAllister (1970, map sheet) reports prominent gypsum units and common gypsiferous beds and anhydrite deposits in the sedimentary sequences of the Furnace Creek Formation. The formation also contains principal deposits of borate and beds of other evaporites, including marl and limestone. Chemical analysis of ground-water collected from a mine shaft in the Furnace Creek Formation (T.26 N., R. 2E, sec. 5) shows the ground-water to contain $2900 \mathrm{mg} / \mathrm{L}$ of sulfate (Miller, 1977, his Table 3). Likewise, the chemical contents of ground-water that is in contact with the Funeral Formation issuing from McLean Spring and a series of springs (informally named the Salt Creek springs) in the Salt Creek Hills north of Cottonball Basin, exhibit high sulfate content (Miller, 1977; Hunt et al., 1966. In contrast, the waters discharging at the Furnace Creek springs contain only moderate concentrations of sulfate (Steinkampf and Werrell, 2001). Ground-water from an aquifer in the Furnace Creek Formation would be high in sulfate content, a condition not reflected in the chemical composition of the Furnace Creek springs, suggesting the waters did not emanate from, or travel long distances through this formation. According to McAllister (1970), Texas, Travertine, and Nevares Springs, as well as Navel Spring, all issue from the Funeral Formation.

\section{Interpretation of stable isotope in the Furnace Creek springs}

Nelson et al. (2004), citing Anderson (2002), indicate that ${ }^{18} \mathrm{O} /{ }^{16} \mathrm{O}$ and ${ }^{2} \mathrm{H} /{ }^{1} \mathrm{H}$ ratios (hereafter $\delta^{18} \mathrm{O}$ and $\delta \mathrm{D}$ ) of mountain spring discharge in the Funeral and Black Mountains are more positive than the values in the discharge of Nevares, Texas, and Travertine Springs. Nelson et al. (2004) note that the $\delta^{18} \mathrm{O}$ and $\delta \mathrm{D}$ of the Furnace Creek springs ( -13.3 and -101.9 , respectively) are similar isotopically to groundwaters in areas "up gradient," (outside of Death Valley). Rather than conclude that the source of the springs is outside the topographic basin, as indicated by their similar isotopic composition to up gradient ground-water, they argue instead that the waters discharging from the Furnace Creek springs were recharged during the late Pleistocene, a time when the isotopic composition of precipitation was lower (more negative) than today.

Winograd et al. (2005) point out that 7 of the 10 carbon-14 ages presented by Anderson (2002, her Table 8 ) for waters discharging from Nevares, Texas, and Travertine Springs indicate Holocene ages (the range of these numbers is 5000-14,500 years with a median of 11000 years). The remaining ages could reflect waters recharged during Holocene climatic conditions. Climatic studies of ice core in Greenland (North Greenland Ice Core Project Members, 2004) and Antarctica (Petit et al., 1999) and paleoclimate records from spring deposits in the southern Great Basin (Winograd et al., 2006; Thomas, 1996; Morse, 2002) indicate that Holocene climatic conditions existed during earlier times in some areas of the DVRFS. Winograd et al. (2006) indicate that several independent lines of evidence indicate that the Furnace Creek spring waters are of Holocene age (or the result of Holocene climatic conditions) and hence their $\delta 180$ and $\delta \mathrm{D}$ content can only be explained by interbasin flow of ground-water into Death Valley.

Isotopic values $\left(\delta^{18} \mathrm{O}\right.$ and $\left.\delta \mathrm{D}\right)$ at Furnace Creek springs, and also at springs located at the base of the Grapevine Mountains, are significantly more depleted than local precipitation (Anderson et al., 2006). $\delta$ D values range from about -102 to -101 per mil at the Furnace Creek springs, and from about -111 to -110 per mil at springs in the Grapevine Springs area. In contrast, $\delta \mathrm{D}$ values in local precipitation, collected in the mid-1980's at the station referred to as Andy, ranged from about -116 to -15.5 per mil (Milne et al., 1987). The cumulative $\delta \mathrm{D}$ for the period between 1991 and 1997 was -75 per mil for the station at Death Valley (Friedman et al., 2002).

Anderson et al. (2006, p. 287) state that the Furnace Creek springs respond to modern climate in terms of discharge rate and minor fluctuations in isotopic composition. Anderson et al. (2006, p. 287) discuss monthly stable isotope data collected from Texas, Travertine, Nevares, Staininger, and Surprise Springs and suggest correlation between Texas and Nevares Springs, Staininger and Surprise Springs, and Nevares and Staininger Springs. The depletion of these isotopic components indicates, to Anderson et al. (2006), that some of the water discharging at the Furnace Creek springs is from modern recharge. 


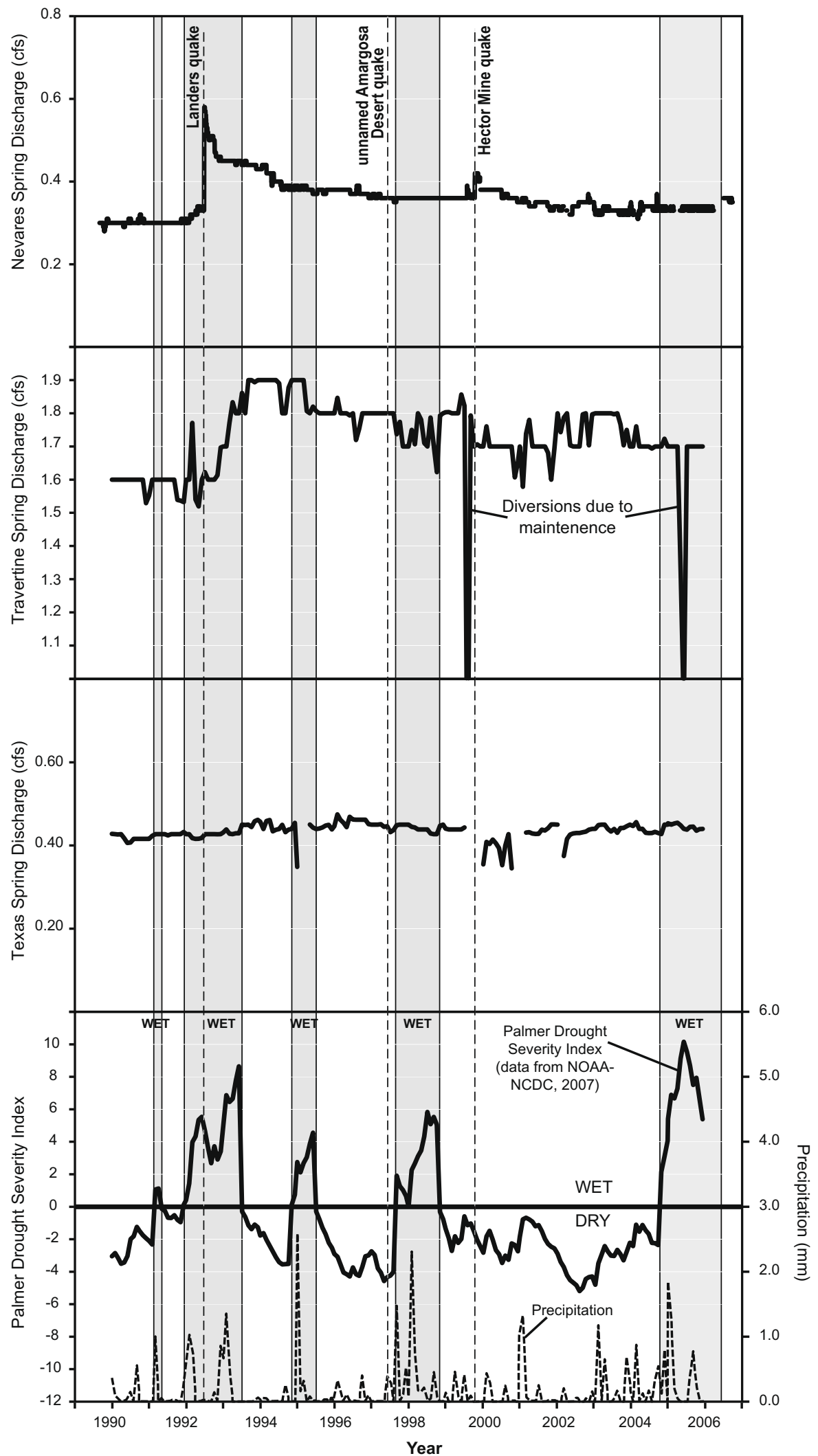

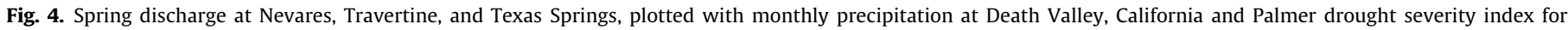
southern Nevada (Division 4).

Anderson et al. (2006, p. 287) state that "Texas and Nevares Springs track each other most closely" and both became isotopically depleted in September 2000 and then again in March 2001. Be- tween early and late September, depletion in $\delta \mathrm{D}$ at the two springs ranged from 0.11 per mil at Texas Spring to 0.23 per mil at Nevares Spring. The only rainfall recorded during this period at the NCDC 
station in Death Valley was about $0.6 \mathrm{~cm}$ at the end of August. As indicated by Anderson et al. (2006), mountain springs, which are indicative of local recharge and local climatic conditions, are significantly more enriched than Nevares, Texas, Travertine, or Staininger Springs. If local precipitation affected spring discharge, isotopic values should become more enriched following precipitation events, not more depleted. Therefore, local recharge cannot cause relatively depleted spring discharge to become even more depleted and local precipitation is not likely to be the cause of the small fluctuation in isotopic values in September 2000 or March 2001.

Isotopic variations of 0.2 per mil for $\delta^{18} \mathrm{O}$ and 1.2 per mil for $\delta \mathrm{D}$ of the time-series data (Anderson et al., 2006, their Fig. 10) are very near the analytical precision of $0.05-0.2$ and $0.2-1.0$ per mil for $\delta^{18} \mathrm{O}$ and $\delta \mathrm{D}$, respectively (Kendall and McDonnell, 1998), raising doubts about the strength of the relationship. Anderson et al. (2006) attempt to address this issue by stating that replicate samples were analyzed repeatedly to better infer the central tendency of specific samples. However, repeated analysis of a sample provides a measure of the instrument precision, not the central tendency of the sample. In addition, the actual values and standard deviation of the replicate samples are not shown, only the mean value is reported. Therefore, it is difficult to come to any conclusion about the robustness of the time-series data. Anderson et al. (2006) do not consider the possibility that some other sampling or laboratory bias, or other physically based bias was introduced to the samples. The very small change in value of $\delta \mathrm{D}$ at the three springs and the lack of consistent response to rainfall events does not support local recharge as a cause for the fluctuations.

$\delta^{18} \mathrm{O}$ values from Texas and Nevares Springs are, in fact, not well correlated. A simple comparison of whether $\delta^{18} \mathrm{O}$ values increase or decrease concordantly at both springs reveals that roughly half the time the trend is in the same direction and the other half the trend is in the opposite direction. A statistical analysis was performed to test this observation. A correlation coefficient was computed and confirmed that there is little or no correlation (Pearson correlation $=0.044, P$-Value $=0.861)$. In contrast, $\delta \mathrm{D}$ values from Texas and Nevares Springs do show evidence for a statistically significant correlation (Pearson correlation $=0.691, P$-Value $=0.002$ ). Similar results are obtained for statistical analyses of the $\delta^{18} \mathrm{O}$ and $\delta \mathrm{D}$ values of Nevares and Staininger Springs. Despite Anderson et al.'s (2006) assertion that both $\delta^{18} \mathrm{O}$ and $\delta \mathrm{D}$ values track one another at Nevares and Staininger Springs, the statistical analysis shows that no correlation is apparent between the $\delta^{18} \mathrm{O}$ values, but correlation is observed in the $\delta \mathrm{D}$ values.

The observation that $\delta \mathrm{D}$ is correlated between springs and $\delta^{18} \mathrm{O}$ is not well correlated suggests that secondary fractionation has occurred. Graphical analysis of the isotopic values of the springs from Anderson (2002) plotted with the meteoric water line (Fig. 5) strongly suggests isotopic enrichment in spring samples due to evaporation. Secondary fractionation during evaporation results in enriched isotopic values that plot below the meteoric water line (Clark and Fritz, 1997). Hershey and Mizell (1995) and Steinkampf and Werrell (2001) both reported $\delta^{18} \mathrm{O}$ values ranging from 0.2 to 0.6 per mil lighter than the spring data reported by Anderson (2002).

The amount of isotopic enrichment that occurs is largely dependent on humidity (or soil moisture), and in arid environments, isotopic enrichment due to evaporation can be significant. A line drawn through the data on a $\delta^{18} \mathrm{O}-\delta \mathrm{D}$ plot would theoretically intercept the meteoric water line at a point that reflects the original isotopic composition of the water. The slope of an evaporation line drawn with the data in Fig. 5 would be very shallow, perhaps as low as 2 .

It is important to note that the spring outlets for the Furnace Creek springs have all been altered to some extent to provide water supply for the park, concessioner, and Timbisha tribe at Furnace
Creek. Nevares Spring issues from several points around a travertine mound overlying the Quaternary alluvium. French drains were constructed to form a collection gallery and plumbed using polyvinyl chloride pipes to carry water downslope to a concrete box where discharge is measured. The pipeline from the collection gallery to the concrete measurement box is about one mile. Travertine Springs is actually a group of springs that discharge from Quaternary alluvium overlying the Funeral and Furnace Creek formations. Four of the spring outlets in this group have been modified by French drains and plumbed to a common discharge line that carries water through a concrete trough to a measurement box. Line 1 is the longest pipeline, carrying water approximately 2800 feet between the collection gallery and the measurement box. Texas Springs discharge is collected by two French drains nearly 200 feet inside an adit dug into the alluvium. Water is conveyed through a concrete channel that runs through the adit. In 1999, a second line was added to convey water inside the adit due to fecal coliform contamination in the open concrete channel. The contamination, due to recurring problems with rodents entering the adits and collection boxes, point out the difficulty in obtaining a representative sample. Researchers are currently not able to enter the Texas Spring adit due to safety concerns, and therefore must obtain samples at the measurement box. Secondary fractionation in the samples may be the result of sampling several hundred feet from the spring collection boxes after spring discharge has come in contact with the atmosphere. The collection galleries, the multiple springs and seeps that make up each spring group, and the diffuse areas of discharge near the spring outlets represent a sampling challenge and may result in slight differences in isotopic values reported by different investigators.

Mass balance modeling and the evaluation of ground-water flow paths Flow paths evaluated by Anderson (2002) and Anderson et al. (2006) do not adequately address possible flow paths and mixing scenarios of water between Ash Meadows and the Furnace Creek springs. Furnace Creek waters are generally thought to be a mixture of waters from the Alkali-Flat/Furnace Creek subbasin (including Jackass Flats, Crater Flat and parts of southeastern Oasis Valley) and the Ash Meadows subbasin of the DVRFS (Steinkampf and Werrell, 2001). Simple mixing calculations using Amargosa Desert wells that were completed in tuff alluvium and a spring in the Ash Meadows area resulted in a composite water similar to Travertine and Nevares springs (Steinkampf and Werrell, 2001). The AlkaliFlat/Furnace Creek subbasin was not evaluated by Anderson et al. (2006).

Anderson et al. (2006, their Fig. 13) compare the ${ }^{13} \mathrm{C} /{ }^{12} \mathrm{C}$ ratio (hereafter $\delta^{13} \mathrm{C}$ ) and percent modern carbon-14 (pmc) in the Furnace Creek and Ash Meadows spring waters and conclude that the differences between them precludes interbasin flow from Ash Meadows to Furnace Creek. If Nelson et al. (2004, their Fig. 3) or Anderson et al. (2006, their Fig. 13) had shown all the published values for these parameters rather a subset of the data (depicted by small black squares on their Fig. 13), readers would readily see that the $\delta^{13} \mathrm{C}$ and pmc for the two populations overlap. It should also be noted that pmc data Pearson and Bodden (1975) and from Hershey and Mizell (1995) are consistently lower for Death Valley springs (for Nevares Spring, 4.8 pmc [Pearson and Bodden, 1975] and 3.6 pmc [Hershey and Mizell, 1995]; for Texas Spring, 5.6 pmc [Pearson and Bodden, 1975] and 3.4 pmc [Hershey and Mizell, 1995]) than the values from Anderson (2002, her Table 3) (for Nevares Spring, $13.6 \mathrm{pmc}$ and for Texas Spring, $17.1 \mathrm{pmc}$ ). These historical data indicate that there may have been a little modern contamination in the Anderson et al. (2006) samples, or perhaps modern contamination during laboratory processing.

Carbon isotopic data, difficult to interpret even in far less complex hydrogeologic settings, do not provide convincing evidence 


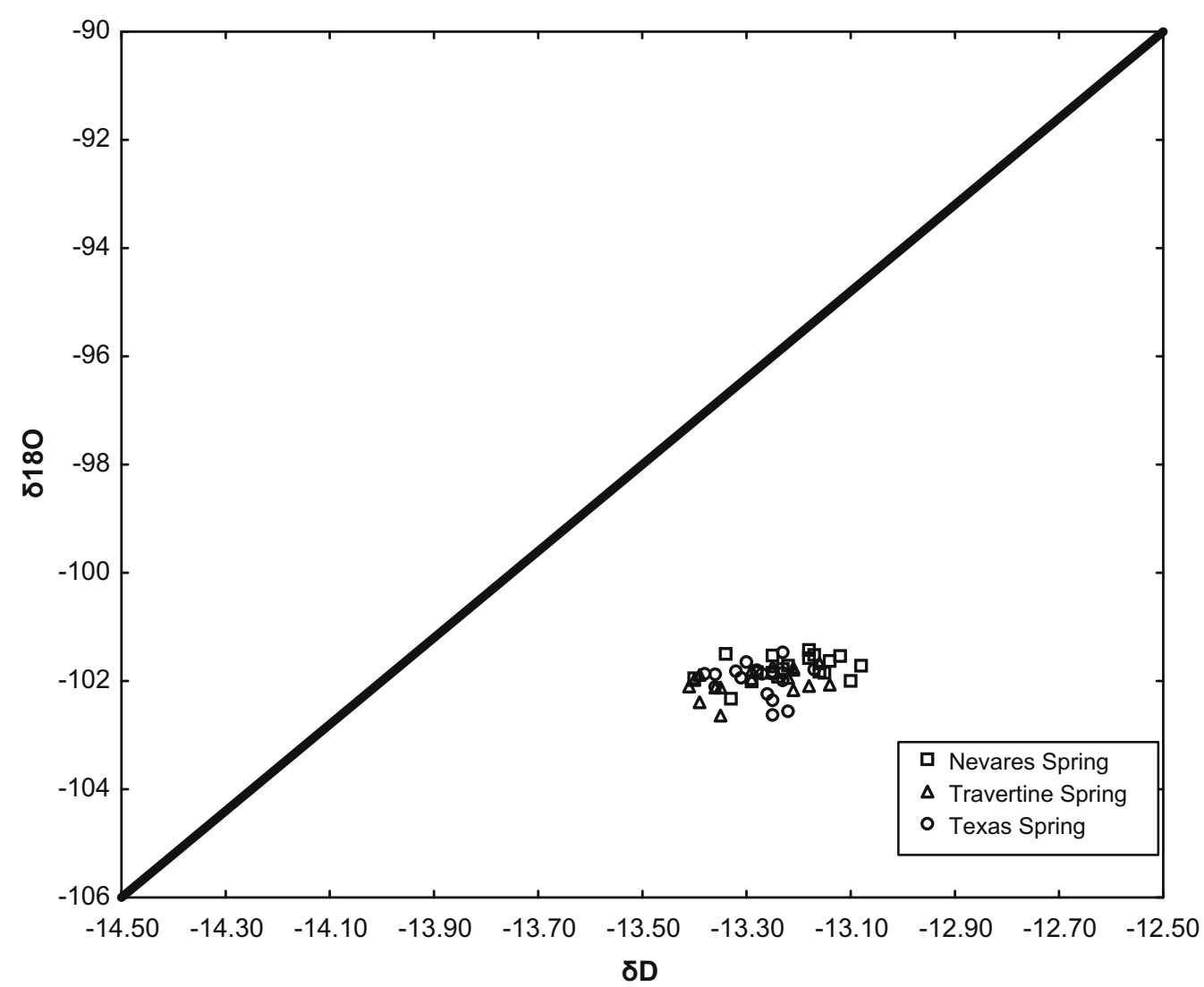

Fig. 5. Deuterium and oxygen-18 values for Furnace Creek springs compared to meteoric water values (spring isotope values from Anderson, 2002).

for or against interbasin movement of ground-water into Furnace Creek. The Furnace Creek springs contain $\delta^{13} \mathrm{C}$ as positive as -3.8 per mil and pmc as low as 3.00 (Steinkampf and Werrell, 2001, their Table 2), while Crystal Pool (the largest spring at Ash Meadows with about 28 percent of the total discharge) has a pmc of about 11 (Winograd and Pearson, 1976). Comparisons of $\delta^{13} \mathrm{C}$ and pmc between the two springs is problematic, given the limited carbon isotopic data, and the well documented non-conservative behavior of these isotopes in carbonate-rock aquifers. The best data for making comparisons, from Pearson and Bodden (1975) show no major difference in $\delta^{13} \mathrm{C}$ between the major springs in the two areas and lower pmc in some Furnace Creek spring waters than at Crystal Pool. Pearson and Bodden's (1975) measurements represent the only known time that major springs in both Furnace Creek and Ash Meadows were sampled at their source, by the same geochemists, using identical sampling procedures and reagents, and the analyses made in the same laboratory.

\section{Conclusions}

The hydrogeologic feasibility of interbasin flow through the Paleozoic rocks of the Funeral Mountains to the Furnace Creek springs has been shown through detailed geologic and hydrologic studies over several decades. Although this paper is primarily concerned with demonstrating that interbasin flow occurs through the southern Funeral Mountains to supply the Furnace Creek springs, historic site investigations and regional studies provide evidence that interbasin flow in the Great Basin region is the norm rather than the exception, even though many studies find local areas where interbasin flow is restricted by low permeability bedrock.

A local source for the Furnace Creek springs derived from Pleistocene recharge to a potential aquifer of the Furnace Creek Forma- tion as proposed by Anderson et al. (2006), is not feasible for the following reasons: (1) the deposits proposed do not constitute a reservoir of sufficient continuity, hydraulic conductivity, or storage to sustain discharge from the end of the Pleistocene to the present time, (2) the proposed potential recharge area of the springs does not receive sufficient recharge to supply the springs, and (3) the chemical solute and isotopic signatures of the ground-water in the Furnace Creek Formation is not compatible with the Furnace Creek springs.

An understanding of the magnitude of interbasin ground-water flow and hydrogeologic processes that control the rate and direction of ground-water flow in eastern and central Nevada is a necessary part of regional ground-water management and waterresource planning in the Great Basin of Nevada. Understanding the ground-water flow paths and travel times in the vicinity of the proposed high-level radioactive waste repository at Yucca Mountain, Nevada and radioactive materials at the Nevada Test Site also depends on the conceptualization of interbasin flow. While many imaginative scenarios can be made to obscure this commonly-accepted interpretation, it remains that interbasin flow is the only readily apparent explanation for the large spring discharges at Furnace Creek. The principle of parsimony demands this conclusion. Solid and overwhelming evidence, deficient in the analysis of Nelson et al. (2004) and Anderson et al. (2006) would be required to overturn the interbasin flow conceptual model for ground-water flow in the Death Valley region or the Great Basin.

\section{References}

Anderson, K.W., 2002. Contribution of Local Recharge to High-flux Springs in Death Valley National Park, California-Nevada. Unpublished Master's Thesis, Brigham Young University, Provo, Utah, 122p. 
Anderson, K., Nelson, S., Mayo, A., Tingey, D., 2006. Interbasin flow revisited: the contribution of local recharge to high-discharge springs, Death Valley, California. Journal of Hydrology 323, 276-302.

Bedinger, M.S., Harrill, J.R., 2004. Appendix 1. Regional potential for interbasin flow. In: Belcher, W.R. (Ed.), Death Valley Regional Ground-Water Flow System, Nevada and California-Hydrogeologic Framework and Transient GroundWater Flow Model. US Geological Survey Scientific Investigations Report 2004-5205, pp. 353-374.

Bedinger, M.S., Harrill, J.R., 2006. Ground-Water Hydrogeology of Death Valley National Park, Nevada and California. Draft Report to the National Park Service, US Department of the Interior, 130p.

Bedinger, M.S., Harrill, J.R., 2007. Hydrogeology of Death Valley [California and Nevada]. Hydrological Science and Technology, American Institute of Hydrology 23 (1-4), 27-38.

Bedinger, M.S., Sargent, K.A., Langer, W.H. (Eds.), 1989a. Studies of Geology and Hydrology in the Basin and Range Province, Southwestern United States, for Isolation of High-level Radioactive Waste-Characterization of the Death Valley Region, Nevada and California. US Geological Survey Professional Paper 1370-F, 49p.

Bedinger, M.S., Langer, W.H., Reed, J.E. 1989b. Ground-water hydrology. In: Bedinger, M.S., Sargent, K.A., Langer, W.H. (Eds.), Studies of Geology and Hydrology in the Basin and Range Province, Southwestern United States, for Isolation of High-Level Radioactive Waste-Characterization of the Death Valley Region, Nevada and California. US Geological Survey Professional Paper 1370-F, pp. 28-35.

Belcher, W.R. (Ed.), 2004. Death Valley Regional Ground-Water Flow System, Nevada and California-Hydrogeologic Framework and Transient GroundWater Flow Model. US Geological Survey Scientific Investigations Report 2004-5205, 408p.

Belcher, W.R., Elliott, P.E., Geldon, A.L., 2001. Hydraulic-Property Estimates for Use with a Transient Ground-Water Flow Model for the Death Valley Regional Ground-Water Flow System, Nevada and California. US Geological Survey Water-Resources Investigations Report 01-4210, 28p.

Belcher, W.R., D’Agnese, F.A., O’Brien, G.M., 2004. A. Introduction. In: Belcher, W.R. (Ed.), Death Valley Regional Ground-Water Flow System, Nevada and CaliforniaHydrogeologic Framework and Transient Ground-Water Flow Model. US Geological Survey Scientific-Investigations Report 2004-5205, pp. 3-19.

Blakely, R.J., Ponce, D.A., 2001. Map Showing Depth to Pre-Cenozoic Basement in the Death Valley Ground-Water Model Area, Nevada and California: US Geological Survey Miscellaneous Field Studies Map MF-2381-E, 1 Sheet, 6p.

Bredehoeft, J.D., Back, W., Hanshaw, B.B., 1982. Regional ground-water flow concepts in the United States-historical perspective. In: Narasimhan, T.N. (Ed.), Recent Trends in Hydrogeology. Geological Society of America, pp. 297316 (Special Paper 189).

Bredehoeft, J., Fridrich, C., King, M., Jansen, J., 2005a. Death Valley Lower Carbonate Aquifer Monitoring Program-Wells Down Gradient of the Proposed Yucca Mountain Nuclear Waste Repository. Inyo County Yucca Mountain Repository Assessment Office, Final Project Report, Prepared Under US Department of Energy Cooperative Agreement, 39p.

Bredehoeft, J., Fridrich, C., King, M., 2005b. The lower carbonate aquifer as a barrier to radionuclide transport. In: WM [Waste Management] '05, February 27March 3, 2005, Tucson, AZ, WM-582, 14p.

Carpenter, E., 1915. Ground Water in Southeastern Nevada. US Geological Survey Water-Supply Paper 365, 86p.

Carr, W.J., 1988. Geology of the Devils Hole Area, Nevada. US Geological Survey Open-File Report 87-560, 34p.

Cemen, Ibrahim, Wright, L.A., Drake, R.E., Johnson, F.C., 1985. Cenozoic sedimentation and sequence of deformational events at the southeastern end of the Furnace Creek strike-slip fault zone, Death Valley region, California. In: Biddle, K.T., Christie-Blick, Nicholas (Eds.), Strike-slip Deformation and Basin Formation. Society of Economic Paleontologists and Mineralogists, pp. 127-141 (Special Publication 37).

Clark, I.D., Fritz, P., 1997. Environmental isotopes in geology. CRC Press. 328p.

D’Agnese, F.A., Faunt, C.C., Turner, A.K., Hill, M.C., 1997. Hydrogeologic Evaluation and Numerical Simulation of the Death Valley Regional Ground-Water Flow System, Nevada and California. US Geological Survey Water-Resources Investigations Report 96-4300, 124p.

Dettinger, M.D., Schaefer, D.H., 1996. Hydrogeology of Structurally Extended Terrain in the Eastern Great Basin of Nevada, Utah, and Adjacent States, from Geologic and Geophysical Models. US Geological Survey Hydrologic Atlas 694-D, 4 maps.

Dettinger, M.D., Harrill, J.R., Schmidt, D.L., 1995. Distribution of Carbonate-Rock Aquifers and the Potential for their Development, Southern Nevada and Adjacent Parts of California, Arizona, and Utah. US Geological Survey WaterResources Investigations Report 91-4146, 100p.

Eakin, T.E., 1966. A regional interbasin ground water system in the White River area, southeastern Nevada. Water Resources Research 2, 251-271.

Eakin, T.E., Moore, D.O., 1964. Uniformity of Discharge of Muddy River springs, Southeastern Nevada, and Relation to Interbasin Movement of Ground Water. In: Geological Survey Research 1964. US Geological Survey Professional Paper 501-D, pp. D171-D176 (Chapter D).

Eakin, T.E., Winograd, I.J., 1965. Interbasin movement of ground water in southcentral Nevada-some implications. In: Abstracts for 1964. Geological Society of America, 52p. (Special Paper 82).

Faunt, C.C., 1997. Effect of Faulting on Ground-Water Movement in the Death Valley Region, Nevada and California. US Geological Survey Water-Resources Investigations Report 95-4132, 42p.
Fee, J.A., Gaudette, H.E., Lyons, W.B., Long, D.T., 1992. Rare earth element distribution in the Lake Tyrrell groundwaters, Victoria, Australia. Chemical Geology 96, 67-93.

Fenelon, J.M., Moreo, M.T., 2002. Trend Analysis of Ground-Water Levels and Spring Discharge in the Yucca Mountain Region, Nevada and California, 1960-2000. US Geological Survey Water-Resources Investigations Report 02-4178, 97p.

Fridrich, C., Workman, J., Blakely, R., Bredehoeft, J., Jansen, J., Thompson, R., King, M. 2003a. Hydrogeologic framework of the southeastern Funeral Mountains, California-Nevada and implications for the major water-supply springs in Death Valley National Park. EOS, Transactions of the American Geophysical Union 84, F627.

Fridrich, C., Blakely, R., Thompson, R., 2003b. Hydrogeologic Investigations of the Southern Funeral Mountains, Part I. Studies in FY 2002. US Geological Survey Administrative Report to Inyo County, California, August 5, 2003, pp. 1-7.

Fridrich, C., Blakely, R., Thompson, R., 2003c. Hydrogeologic Investigations of the Southern Funeral Mountains, Part I. Studies in 2003. US Geological Survey Administrative Report to Inyo County, California, August 5, 2003, pp. 8-24.

Friedman, I., Smith, G.I., Johnson, C.A., Moscati, R.J., 2002. Stable isotope composition of water in the Great Basin, United States. 2. Modern precipitation. Journal of Geophysical Research 107, 15-1-15-22.

Greene, R.C., 1997. Geology of the Northern Black Mountains, Death Valley, California. US Geological Survey Open-File Report 97-79, 3 Plates, Scale $1: 24,000,82 \mathrm{p}$.

Hanks, T.C., Winograd, I.J., Anderson, R.E., Reilly, T.E., Weeks, E.P., 1999. Yucca Mountain as a Radioactive-Waste Repository. US Geological Survey Circular C1184, 19p.

Harrill, J.R., Prudic, D.E., 1998. Aquifer Systems in the Great Basin Region of Nevada Utah, and Adjacent States. US Geological Survey Professional Paper 1409-A, 66p.

Harrill, J.R., Gates, J.S., Thomas, J.M., 1988. Major Ground-Water Flow Systems in the Great Basin Region of Nevada, Utah, and Adjacent states. US Geological Survey Hydrologic Investigations Atlas HA-694-C, scale 1:1,000,000.

Hershey, R.L., Mizell, S.A., 1995. Water Chemistry of Spring Discharge from the Carbonate-Rock Province of Nevada and California. Desert Research Institute, Water Resources Center, Publication 41140, 6 Appendix, 42p.

Hunt, C.B., Robinson, T.W., 1960. Possible Interbasin Circulation of Ground Water in the Southern Part of the Great Basin. US Geological Survey Professional Paper 400-B, pp. B273-B274

Hunt, C.B., Robinson, T.W., Bowles, W.A., Washburn, A.L., 1966. Hydrologic Basin Death Valley California. US Geological Survey Professional Paper 494-B, pp. B1B147.

Johannesson, K.H., Stetzenbach, K.J., Hodge, V.F., Kreamer, D.K., Zhou, X., 1997. Delineation of groundwater flow systems in the southern Great Basin using aqueous rare earth element distributions. Ground Water 35, 807-819.

Kendall, C., McDonnell, J.J. (Eds.), 1998. Isotope Tracers in Catchment Hydrology. Elsevier Science, p. 839

Machette, M.N., Stephenson, W.J., Williams, R.A., Odum, J.K., Worley, D.M., Dart, R.L., 2000. Seismic-Reflection Investigations of the Texas Springs Syncline for Ground Water Development, Death Valley National Park. US Geological Survey Open-File Report 00-106, 26p.

Mase, C.W., Galanis, S.P., Jr., Monroe, R.J., 1979. Near surface heat flow in Saline Valley, California. US Geological Survey Open-File Report 79-1136, 52p.

Maxey, G.B., Eakin, T.E., 1949. Ground Water in White River Valley, White Pine, Nye and Lincoln Counties, Nevada. Nevada State Engineer, Water Resources Bulletin Number 8, 59p.

McAllister, J.F., 1970. Geology of the Furnace Creek Borate Area, Death Valley, Inyo County, California. California Department of Conservation, Division of Mines and Geology Map Sheet 14, Scale 1:24,000, with accompanying text

McAllister, J.F., 1971. Preliminary Geologic Map of the Funeral Mountains in the Ryan Quadrangle, Death Valley Region, Inyo County, California. US Geological Survey Open-File Report 71-187, 1:31,680 Scale.

McAllister, J.F., 1973. Geologic Map and Sections of the Amargosa Valley Borate Area-southeast continuation of the Furnace Creek area, Inyo County, California. US Geological Survey Miscellaneous Geologic Investigations Map I-782, 1 Sheet, Scale $1: 24,000$

McAllister, J.F., 1974. Geologic maps and sections of a strip from Pyramid Peak to the southeast end of the Funeral Mountains, Ryan Quadrangle, California. In: Guidebook - Death Valley Region, California and Nevada, Shoshone, California. The Death Valley Publishing Company, pp. 81-83.

Mendenhall, W.C., 1909. Some Desert Watering Places in Southeastern California and Southwestern Nevada. US Geological Survey Water-Supply Paper 224, 86p.

Mifflin, M.D., 1968. Delineation of Ground-Water Flow Systems in Nevada. Desert Research Institute, University of Nevada System, Technical Report Series H-W, Publication No. 4, 103p.

Mifflin, M.D., Hess, J.W., 1969. Regional carbonate flow systems in Nevada. Journa of Hydrology 43, 217-237.

Miller, G.A., 1977. Appraisal of Water Resources of Death Valley, California. US Geological Survey Open-File Report 77-728, 68p.

Milne, W.K., Benson, L.V., McKinley, P.W., 1987. Isotope Content and Temperature of Precipitation in Southern Nevada, August 1983-August 1986. US Geological Survey Open-File Report 87-463, 32p.

Morse, B.S., 2002. Radiocarbon Dating of Groundwater Using Paleoclimate Constraints and Dissolved Organic Carbon in the Southern Great Basin, Nevada and California. Unpublished Master's Thesis, University of Nevada, Reno, Nevada, 63p.

Muir-Wood, R., King, G.C.P., 1993. Hydrological signature of earthquake strain. Journal of Geophysical Research 98, 22035-22068. 
National Oceanic and Atmospheric Administration-National Climate Data Center (NOAA-NCDC), 2007. <http://www.ncdc.noaa.gov/oa/climate/onlineprod/ drought/xmgr.html> (accessed 11.01.07).

Nelson, S.T., Anderson, K., Mayo, A.L., 2004. Testing the interbasin flow hypothesis at Death Valley, California. EOS 85, 349. 355-356.

North Greenland Ice Core Project Members, 2004. High resolution record of northern hemisphere climate extending into the last interglacial period. Nature 431, 147-151.

Pearson Jr., F.J., Bodden, M., 1975. US Geological Survey, Water Resources Division, radiocarbon measurements I. Radiocarbon 17, 135-148.

Petit, J.R., Jouzel, J., Raynaud, D., Barkov, N.I., Barnola, J.-M., Basile, I., Bender, M., Chappellaz, J., Davis, M., Delaygue, G., Delmotte, M., Kotlyakov, V.M., Legrand, M., Lipenkov, V.Y., Lorius, C., PE'pin, L., Ritz, C., Saltzman, E., Stievenard, M. 1999. Climate and atmospheric history of the past $4,20,000$ years from the Vostok ice core, Antarctica. Nature 399, 429-436.

Pistrang, M.A., Kunkel, F., 1964. A Brief Geologic and Hydrologic Reconnaissance of the Furnace Creek Wash Area, Death Valley National Monument, California. US Geological Survey Water-Supply Paper 1779-Y, map scale 1:24,000, 1 pl, 36p.

Raines, G.L., Connors, K.A., Moyer, L.A., Miller, R.J., 2003. Spatial digital database fo the geologic map of Nevada. In: Stewart, J.H., Carlson, J.E. (Eds.), US Geological Survey Open-File Report 03-66, Digital database, version 3.0, 33p.

Riggs, A.C., Carr, W.J., Kolesar, P.T., Hoffman, R.J., 1994. Tectonic speleogenesis of Devils Hole, Nevada, and implications for hydrology and the development of long continuous paleoenvironmental records. Quaternary Research 42, 241 254.

Roeloffs, E.A. Danskin, W.R, Farrar, C.D., Galloway, D.L., Hamlin, S.N., Quilty, E.G. Quinn, H.M., Schaefer, D.H., Sorey, M.L., Woodcock, D.E., 1995. Hydrologic Effects Associated with the June 28, 1992 Landers, California, Earthquake Sequence. US Geological Survey Open-File Report 95-42, 68p.

Rojstaczer, S., Wolf, S., 1992. Permeability changes associated with large earthquakes, an example from Loma Prieta, California. Geology 20, 211214.

Rowlands, P.G. 1993. Vegetation and climate of Death Valley National Monument and the adjacent Mojave and Great Basin Deserts, California and Nevada. In: Proceedings of the Fourth Conference on Research in California's National Parks, National Park Service, National Park Service Transactions and Proceedings Series, vol. 9, pp. 66-82.

Saucedo, G.J., Bedford, D.R., Raines, G.L., Miller, R.J., Wentworth, C.M., 2000. Digital Data for the Geologic Map of California. California Department of Conservation, California Geological Survey CD 2000-2006, Sacramento, California.

Scott, B.R., Smales, T.J., Rush, F.E., Van Denburgh, A.S., 1971. Nevada's Water Resources. Nevada Division of Water Resources, Water for Nevada Report 3 87p.

Smedley, P.L., 1991. The geochemistry of rare earth elements in groundwater from the Carnmenellis area, southwest England. Geochimica Cosmochimica Acta 55, 2767-2779.
Steinkampf, W.C., Werrell, W.L., 2001. Ground-Water Flow to Death Valley as Inferred from the Chemistry and Geohydrology of Selected Springs in Death Valley National Park, California and Nevada. US Geological Survey WaterResources Investigations Report 98-4114, 37p.

Stewart, J.H., 1983. Extensional tectonics in the Death Valley area, California; transport of the Panamint Range structural block $80 \mathrm{~km}$ northwestward. Geology 11, 153-157.

Thomas, J.M., 1996. Geochemical and Isotopic Interpretation of Groundwater Flow, Geochemical Processes, and Age Dating Of Groundwater in the Carbonate-Rock Aquifers of the Southern Basin and Range. Unpublished Ph.D. Dissertation, University of Nevada, Reno, Nevada, 135p.

Winograd, I.J. 1963. A summary of the ground-water hydrology of the area between Las Vegas Valley and the Amargosa Desert, Nevada, with special reference to the effects of possible new withdrawals of ground water. In: US Congress, Nevada Test Site Community, Hearings Before Joint Committee on Atomic Energy, US 88th Congress, 1st Session, September and October 1963, pp. 197-226 (also published as US Geological Survey Open-File Report TEI-840, 79p.).

Winograd, I.J., Pearson Jr., F.J., 1976. Major carbon-14 anomaly in a regional carbonate aquifer: possible evidence for megascale channeling, southcentral Great Basin. Water Resources Research 12, 1125-1143.

Winograd, I.J., Thordarson, William, 1975. Hydrogeologic and Hydrochemical Framework, South-Central Great Basin, Nevada-California, with Special Reference to the Nevada Test Site. US Geological Survey Professional Paper 712-C, 3 plates, $126 \mathrm{p}$.

Winograd, I.J., Fridrich, C.F., Sweetkind, D., Belcher, W.R., Thomas, J.M., 2005. Comment on "Testing the interbasin flow hypothesis at Death Valley, California". EOS, Transactions of the American Geophysical Union 86, 295-296.

Winograd, I.J., Landwehr, J.M., Coplen, T.B., Sharp, W.D., Riggs, A.C., Ludwig, K.R., Kolesar, P.T., 2006. The Devils Hole, Nevada, $\delta^{18} \mathrm{O}$ record extended to the midHolocene. Quaternary Research 66, 202-212.

Workman, J.B., Menges, C.M., Page, W.R., Taylor, E.M., Ekren, E.B., Rowley, P.D., Dixon, G.L., Thompson, R.A., Wright, L.A., 2002. Geologic Map of the Death Valley Ground-Water Model Area, Nevada and California. US Geological Survey Miscellaneous Field Studies Map MF-2381-A, scale 1:250,000. 1 plate with pamphlet.

Wright, L.A., Thompson, R.A., Troxel, B.W., Pavlis, T.L., DeWitt, E., Otton, J.K., Ellis, M.A., Miller, M.G., Serpa, L.F., 1991. Cenozoic magmatic and tectonic evolution of the east-central Death Valley region, California. In: Walawender, M.J., Hanan, B.B. (Eds.), Geological Excursions in Southern California and Mexico. Geological Society of America Annual Meeting Guidebook 1991. Geological Society of America, Boulder, Colorado, pp. 93-127.

Wright, L.A., Greene, R.C., Cemen, I., Johnson, F.C., Prave, A.R., 1999. Tectonostratigraphic development of the Miocene-Pliocene Furnace Creek Basin and related features, Death Valley Region, California. In: Wright, L.A., Troxel, B.W. (Eds.), Cenozoic basins of the Death Valley region. Geological Society of America, Boulder, Colorado, pp. 87-114 (Special Paper 333). 